\title{
Information about the Effect of Climatic Factors and Soil Moisture Status on Cotton Production using Different Statistical Relations
}

\author{
Zakaria M Sawan* \\ Cotton Research Institute, Egypt \\ *Corresponding author: Zakaria M Sawan,Cotton Research Institute, Agricultural Research Center, Ministry of Agriculture \& Land Reclamation, 9 \\ Gamaa Street, 12619, Giza, Egypt
}

Submission: April 11, 2018; Published: July 10, 2018

\begin{abstract}
Understanding the impacts of climatic factors on cotton production may help physiologists to determine the control mechanisms of boll retention in cotton. However, weather affects crop growth interactively, sometimes resulting in unexpected responses to prevailing conditions. Field trials, using cotton G. barbadense were carried out, to investigate the relationships between climatic factors, soil moisture status, and flower and boll production. The climatic factors considered were, i.e., daily data of maximum air temperature $\left({ }^{\circ} \mathrm{C}\right)$, minimum air temperatures $\left({ }^{\circ} \mathrm{C}\right)$, maximum-minimum temperature (diurnal temperature range or temperature magnitude) $\left({ }^{\circ} \mathrm{C}\right)$, sunshine duration $\left(\mathrm{hd}^{-1}\right)$, maximum humidity $(\%)$, minimum humidity $(\%)$ and wind speed $\left(\mathrm{ms}^{-1}\right)$. It could be generally concluded that minimum humidity (water stress) and sunshine duration, were the most significant climatic factors affecting cotton flower and boll production and retention in Egyptian. Temperature appeared to be less important in the reproduction growth stage of cotton in Egypt than minimum humidity and sunshine duration. The soil moisture status showed low and insignificant correlation to flower and boll production. The positive correlation between minimum humidity value along with the negative correlation between each ofhigh maximum air temperature (temperature equalled or exceeded $37.5^{\circ} \mathrm{C}$ ) and sunshine duration with flower and boll formation, indicate that high value of minimum humidity, short period of sunshine duration and low value of temperature would enhance flower and boll formation.
\end{abstract}

Keywords: Cotton flower and boll production; Humidity; Soil moisture status; Sunshine duration; Temperature

\section{Introduction}

Cotton yield is a function of growth rates, flower production rates, and flower and boll retention during the fruiting period. Information on the relationship between climatic factors and the cotton plant's ability to produce and sustain flower buds, flowers, and bolls will allow one to model plant responses to conditions that frequently occur in the field and to predict developmental rate or the formation of these organs. As the knowledge of the impact of climatic factors on cotton production is not generally available, or at least not available in the required form, so, understanding of this impact may help the physiologists to determine a possible control of flowering mechanism in cotton plant. However, weather affects crop growth interactively, sometimes resulting in unexpected responses to prevailing conditions. The balance between vegetative and reproductive development can be influenced by soil fertility, soil moisture, cloudy weather, spacing and perhaps other factors such as temperature and relative humidity. The early prediction of possible adverse effects of climatic factors might modify their effect on production of cotton Sawan [1].
Climate affects crop growth interactively, sometimes resulting in unexpected responses to prevailing conditions. Many factors, such as length of the growing season, climate (including solar radiation, temperature, light, wind, rainfall, and dew), cultivar, availability of nutrients and soil moisture, pests and cultural practices affect cotton growth (El-Zik 1980). The balance between vegetative and reproductive development can be influenced by soil fertility, soil moisture, cloudy weather, spacing and perhaps other factors such as temperature and relative humidity Guinn [2]. Weather, soil, cultivars, and cultural practices affect crop growth interactively, sometimes resulting in plants responding in unexpected ways to their conditions Sawan [1]. Water is a primary factor controlling plant growth. Xiao [3] stated that, when water was applied at 0.85, $0.70,0.55$ or $0.40 \mathrm{ET}$ (evapotranspiration) to cotton plants grown in pots, there was a close relationship between plant development and water supply. The fruit-bearing branches, square and boll numbers and boll size were increased with increased water supply. Barbour \& Farquhar [4] reported on greenhouse pot trials where cotton cv. CS50 plants were grown at 43 or $76 \%$ relative humidity 
(RH) and sprayed daily with abscisic acid (ABA) or distilled water. Plants grown at lower RH had higher transpiration rates, lower leaf temperatures and lower stomatal conductance. Plant biomass was also reduced at the lower RH. Within each RH environment, increasing ABA concentration generally reduced stomatal conductance, evaporation rates, superficial leaf density and plant biomass, and increased leaf temperature and specific leaf area.

Temperature is also a primary factor controlling rates of plant growth and development. Burke [5] has defined the optimum temperature range for biochemical and metabolic activities of plants as the thermal kinetic window (TKW). Plant temperatures above or below the TKW result in stress that limits growth and yield. The TKW for cotton growth is 23.5 to $32{ }^{\circ} \mathrm{C}$, with an optimum temperature of $28{ }^{\circ} \mathrm{C}$. Biomass production is directly related to the amount of time that foliage temperature is within the TKW. Schrader et al. [6] stated that high temperatures that plants are likely to experience inhibit photosynthesis. Species/cultivars that retain fruits at high temperatures would be more productive both in the present-day cotton production environments and even more in future warmer world Sawan [7].

Zhou [8] indicated that light duration is the key meteorological factor influencing the wheat-cotton cropping pattern and position of the bolls, while temperature had an important function on upper (node 7 to 9) and top (node 10) bolls, especially for double cropping patterns with early maturing varieties. The objective of this investigation was to study the effect of various climatic factors (to provide quantitative estimate) and soil moisture status (soil moisture irrigation) during the production stage on the overall flower and boll production in Egyptian cotton. This could pave the way for formulating advanced predictions as to the effect of certain climatic conditions on cotton production of Egyptian cotton. It would be useful to minimize the deleterious effects of the factors through utilizing proper cultural practices which would limit and control their negative effects, and this will lead to an improve in cotton yield. We tested the hypothesis that an understanding of the relationships between climatic factors (to provide quantitative estimate), flowering and boll retention patterns of the cotton plant may allow a direct external intervention that can help cotton growth and production.

\section{Materials and Methods}

Two uniform field trials were conducted at the experimental farm of the Agricultural Research Center, Ministry of Agriculture, Giza, Egypt ( $30^{\circ} \mathrm{N}, 31^{\circ}: 28^{\prime} \mathrm{E}$ at an altitude $\left.19 \mathrm{~m}\right)$, using the cotton cultivar Giza 75 (Gossypium barbadense L.) in 2 successive seasons (I and II). The soil texture was a clay loam, with an alluvial substratum ( $\mathrm{pH}=8.07,42.13 \%$ clay, $27.35 \%$ silt, $22.54 \%$ fine sand, $3.22 \%$ coarse sand, $2.94 \%$ calcium carbonate and $1.70 \%$ organic matter) Sawan [9].

In Egypt, there are no rain-fed areas for cultivating cotton, and hence the location at which the field trials were conducted was irrigated regularly using the surface irrigation technique. Total water consumptive during each of two growing seasons supplied by surface irrigation was about $6,000-\mathrm{m}^{3} \mathrm{~h}^{-1}$. The criteria used for watering the crop depended on soil water status, where irrigating was applied when soil water content reached about $35 \%$ of field capacity $(0-60 \mathrm{~cm})$. In season I, the field was irrigated on $15 \mathrm{March}$ (at planting), 8 April (first irrigation), 29 April, 17 May, 31 May, 14 June, 1 July, 16 July, and 12 August. In season II, the field was irrigated on 23 March (planting date), 20 April (first irrigation), 8 May, 22 May, 1 June, 18 June, 3 July, 20 July, 7 August and 28 August. Techniques normally used for growing cotton in Egypt were followed. Each experimental plot contained 13 to15 ridges to facilitate proper surface irrigation. Ridge width was $60 \mathrm{~cm}$ and its length was $4 \mathrm{~m}$. Seeds were sown on 15 and 23 March in seasons I and II, respectively, in hills $20 \mathrm{~cm}$ apart on one side of the ridge. Seedlings were thinned to 2 plants per hill 6 weeks after planting, resulting in a plant density of about 166,000 plants ha${ }^{1}$. Phosphorus fertilizer was applied at a rate of $54 \mathrm{~kg} \mathrm{P}_{2} \mathrm{O}_{5} \mathrm{ha}^{-1}$ as calcium super phosphate during land preparation. Potassium fertilizer was applied at a rate of $57 \mathrm{~kg} \mathrm{~K}_{2} \mathrm{O} \mathrm{ha}{ }^{-1}$ as potassium sulfate before the first irrigation (as a concentrated band close to the seed ridge). Nitrogen fertilizer was applied at a rate of $144 \mathrm{kgN} \mathrm{ha}^{-1}$ as ammonium nitrate 2 equal doses: the first applied after thinning just before the second irrigation and the other applied before the third irrigation (in the form of pinches beside each hill). Rates of phosphorus, potassium, and nitrogen fertilizer were the same in both seasons. These amounts were determined based on the use of soil test guidelines Sawan [9].

After thinning, 261 and 358 plants were randomly selected (precaution of border effect was taken into consideration by discarding the cotton plants in the first and last 2 hills each ridge) from 9 and 11 inner ridges of the plot seasons I, and II respectively. Pest control management was carried out on an-as-needed basis, according to local practice performed at the experimental station. Flowers on all selected plants were tagged in order to count and record the number of open flowers, and set bolls on a daily basis. The flowering season commenced on the date of the first flower appearance and continued until the end of flowering season (31 August), which would give sound bolls (50 days old) at the end of the handpicking season (20 October). In season I, the flowering period extended from 17 June to 31 August, whereas in season II, the flowering period was from 21 June to 31 August. Flowers produced after 31 August were not expected to form sound harvestable bolls, and therefore were not taken into account. For statistical analysis, the following data of the dependent variables were determined: (1) daily number of tagged flowers separately counted each day on all selected plants uniform plants $\left(\mathrm{Y}_{1}\right)$ and $(2)$ number of retained bolls obtained from the total daily tagged flowers on all selected plants at harvest $\left(\mathrm{Y}_{2}\right)$.

As a rule, observations were recorded when the number of flowers on a given day was at least 5 flowers found for a population of 100 plants and this continued for at least five consecutive days. This rule omitted eight observations in the first season and ten observations in the second season. So the number of observations (n) was 68 (23 June through 29 August) and 62 (29 June through 29 August) for the two seasons, respectively Sawan [9]. The soil 
moisture statuses considered were, i.e., day of irrigation, the first and second day after the day of irrigation and the day prior to the day of irrigation.

The climatic factors considered were, i.e., daily data of maximum air temperature $\left({ }^{\circ} \mathrm{C}\right)$, minimum air temperatures $\left({ }^{\circ} \mathrm{C}\right)$, maximumminimum temperature (diurnal temperature range or temperature magnitude) $\left({ }^{\circ} \mathrm{C}\right)$, sunshine duration $\left(\mathrm{hd}^{-1}\right)$, maximum humidity $(\%)$, minimum humidity (\%) and wind speed $\left(\mathrm{ms}^{-1}\right)$, (in season II only).
The source of the climatic data was the Agricultural Meteorological Station of the Agricultural Research Station, Agricultural Research Center, Giza, Egypt. No rainfall occurred during the 2 growing seasons. Range and mean values of the climatic parameters (independent variables) recorded during the production stage for both seasons and overall data are listed in Table 1. Daily number of flowers and number of bolls per plant which survival to maturity (dependent variables) during the production stage in the two seasons are graphically illustrated in Figures 1 \& 2; Sawan [9].

Table 1: Range and mean values of the independent variables (climatic factors) for the two seasons and overall the data. *Flower and boll stage (68 days, from 23 June through 29 August). **Flower and boll stage (62 days, from 29 June through 29 August).

\begin{tabular}{|c|c|c|c|c|c|c|}
\hline \multirow{2}{*}{ Climatic Factor's } & \multicolumn{2}{|c|}{ First Season* } & \multicolumn{2}{|c|}{ Second Season ${ }^{* *}$} & \multicolumn{2}{|c|}{ Over all Data(Two Seasons) } \\
\hline & Range & Mean & Range & Mean & Range & Mean \\
\hline Max Temp $\left({ }^{\circ} \mathrm{C}\right)$ & $31.0-44.0$ & 34.3 & $30.6-38.8$ & 34.1 & $30.6-44.0$ & 34.2 \\
\hline $\operatorname{Min} \operatorname{Temp}\left({ }^{\circ} \mathrm{C}\right)$ & $18.6-24.5$ & 21.9 & $18.4-23.9$ & 21.8 & $18.4-24.5$ & 21.8 \\
\hline Max-Min Temp $\left({ }^{\circ} \mathrm{C}\right)$ & $9.4-20.9$ & 12.4 & $8.5-17.6$ & 12.2 & $8.5-20.9$ & 12.3 \\
\hline Sunshine $\left(\mathrm{hd}^{-1}\right)$ & $10.3-12.9$ & 11.7 & $9.7-13.0$ & 11.9 & $9.7-13.0$ & 11.8 \\
\hline Max Hum (\%) & $62-96$ & 85.4 & $51-84$ & 73.2 & $51-96$ & 79.6 \\
\hline Min Hum (\%) & $11-45$ & 30.8 & $23-52$ & 39.8 & $11-52$ & 35.1 \\
\hline Wind speed $\left(\mathrm{ms}^{-1}\right)$ & ND & ND & $2.2-7.8$ & 4.6 & ND & ND \\
\hline
\end{tabular}

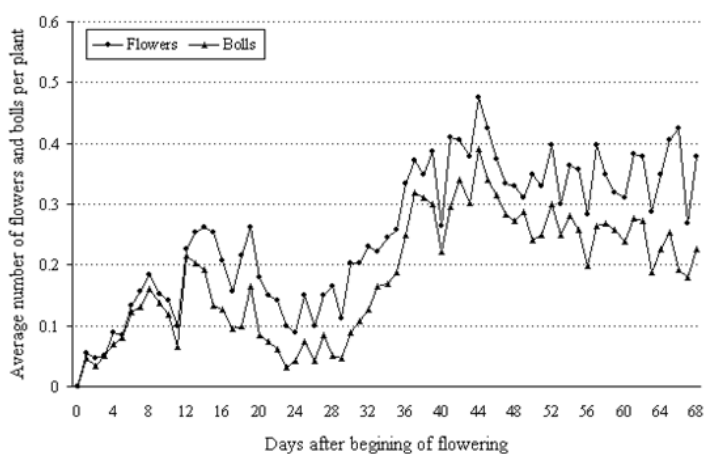

Figure 1: Daily number of flowers and bolls during the production stage (68 days) in the first season (I) for the Egyptian cotton cultivar Giza 75 (Gossypium barbadense L.) grown in uniform field trial at the experimental farm of the Agricultural Research Centre, Giza $\left(30^{\circ} \mathrm{N}, 31^{\circ}: 28^{\prime} \mathrm{E}\right)$, Egypt. The soil texture was a clay loam, with an alluvial substratum, (pH=8.07). Total water consumptive use during the growing season supplied by surface irrigation was about $6000 \mathrm{~m}^{3} \mathrm{ha}^{-1}$. No rainfall occurred during the growing season. The sampling size was 261 plants Sawan [8].

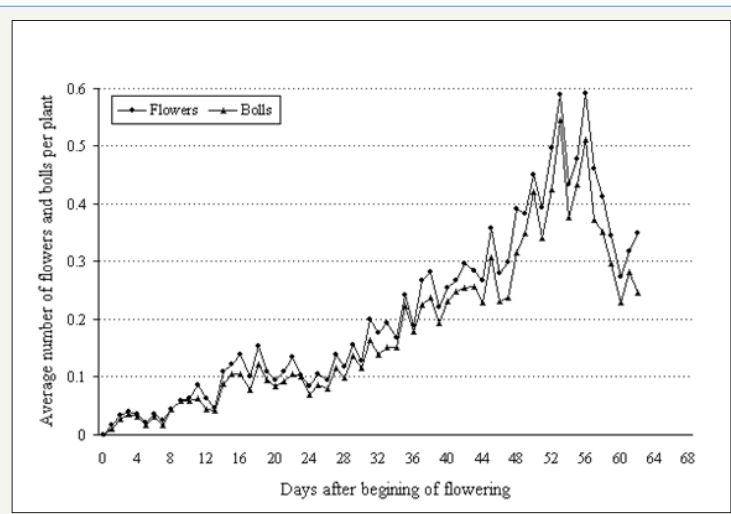

Figure 2: Daily number of flowers and bolls during the production stage (62days) in the second season (II) for the Egyptian cotton cultivar Giza 75 (Gossypium barbadense L.) grown in uniform field trial at the experimental farm of the Agricultural Research Centre, Giza $\left(30^{\circ} \mathrm{N}, 31^{\circ}: 28^{\prime} \mathrm{E}\right)$, Egypt. The soil texture was a clay loam, with an alluvial substratum, (pH=8.07). Total water consumptive use during the growing season supplied by surface irrigation was about $6000 \mathrm{~m}^{3} \mathrm{ha}^{-1}$. No rainfall occurred during the growing season. The sampling size was 358 plants Sawan [8]. 


\section{Basic variables}

A. Dependant variables as defined above: $\left(\mathrm{Y}_{1}\right)$ and $\left(\mathrm{Y}_{2}\right)$.

B. Independent variables (Xs) Sawan [9]:

a. Irrigation on day $1=1$. Otherwise, enter 0.0 (soil moisture status) (X1)

b. The first and second day after the day of irrigation (soil moisture status) $=1$. Otherwise, enter $0.0(\mathrm{X} 2)$.

c. The day prior to the day of irrigation (soil moisture status) to check for possible moisture deficiency on that day=1. Otherwise, enter 0.0 (X3).

d. Number of days during days 1 (day of flowering)-12 (after flowering) that temperature equalled or exceeded $37.5^{\circ} \mathrm{C}$ (high temperature) (X4).

e. Range of temperature (temperature magnitude) $\left[{ }^{\circ} \mathrm{C}\right]$ on day 1 (day of flowering) (X5).

f. Broadest range of temperature $\left[{ }^{\circ} \mathrm{C}\right.$ ] over days 1 (day of flowering)-12 (after flowering) (X6).

g. Minimum humidity [\%] during day 1 (day of flowering) (X7).

h. Maximum humidity [\%] during day 1 (day of flowering) (X8).

i. Minimum humidity [\%] during day 2 (after flowering) (X9).

j. $\quad$ Maximum humidity [\%] during day 2 (after flowering) (X10).

k. Largest maximum humidity [\%] on days 3-6 (after flowering) (X11).

I. Lowest minimum humidity [\%] on days 3-6 (after flowering) (X12).

m. Largest maximum humidity [\%] on days 7-12 (after flowering) (X13).

n. Lowest minimum humidity [\%] on days 7-12 (after flowering) (X14).

o. Lowest minimum humidity [\%] on days 50-52 (after flowering) (X15).

p. Daily light period (hour) (X16).

\section{Statistical Analysis}

Simple correlation coefficients between the initial group of independent variables (climatic factors and soil moisture status; X's) and the corresponding dependent variables (Y's) were computed for each season and the combined data of the two seasons (to determine the significant climatic factors and soil moisture status affecting the cotton production variables). The level for significance was $\mathrm{P}<0.15$. Those climatic factors and soil moisture status attaining a probability level of significance not exceeding 0.15 were deemed important (affecting the dependent variables), combined with dependent variable in multiple regression analysis to obtain a convenient predictive model Cady \& Allen [10]. Multiple linear regression equations (using the stepwise method) comprising selected predictive variables were computed for the determined interval, and coefficients of multiple determination $\left(\mathrm{R}^{2}\right)$ were calculated to measure the efficiency of the regression models in explaining the variation in data (the obtained equations will be used in future according to yearly changes which would happen in the effective climatic factors beside soil moisture status). Correlation and regression analysis were computed according to Draper and Smith, by means of the computer programs SAS package 1985, using the procedures outlined in the general linear model (GLM) SAS Institute Sawan [9].

\section{Result and Discussion}

Daily number of flowers and number of bolls per plant that survived to maturity (dependent variables) during the production stage of the 2 growing seasons (68 and 62d in Seasons I and II, respectively) are illustrated in Figure $1 \& 2$. The flowering- and boll setting-curves reached their peaks during the middle $2 \mathrm{wk}$ of August, and then descended steadily till the end of the season. Specific differences in the shape of these curves in the 2 seasons may be due to the environmental effects on growth, for which climatic factors (Table 1) play an important role Sawan a [7]; Sawan $b$ [12]. The square values of, i.e. number of days during days 1 (day of flowering)-12 (after flowering) that temperature equalled or exceeded $37.5{ }^{\circ} \mathrm{C}$ (high temperature) (X4), minimum humidity during day 1 (day of flowering) (X7), maximum humidity during day 1 (day of flowering) (X8), minimum humidity during day 2 (after flowering) (X9), maximum humidity during day 2 (after flowering) (X10), largest maximum humidity on days 3-6 (after flowering) (X11), lowest minimum humidity on days 3-6 (after flowering) (X12), largest maximum humidity on days 7-12 (after flowering) (X13) and lowest minimum humidity on days 7-12 (after flowering) (X14) were determined and calculated its simple correlation coefficients with the independent variables $\left(\mathrm{Y}_{1}\right.$ and $\left.\mathrm{Y}_{2}\right)$. We studied the curve linear (quadratic form) for these entire $\mathrm{X}$, s, without any important significant effects. Wind speed data were available in the second season only, and it did not show any significant effect upon the studied production variables, so it was not considered. However, these data were in Table 2 and in Materials and methods section Sawan [9].

\section{Correlation estimates}

Results of simple the correlation coefficients between climatic factors, soil moisture status (independent variables) and the initial group of independent variables and each of flower and boll production in the first, and second seasons and the combined data of the two seasons are shown in (Tables 2-4); Sawan [9]. The simple correlation values indicated clearly that humidity seems to be the most important climatic factor as it showed the highest correlation value. Also, this factor had a significant positive relationship with flower and boll production, except of lowest minimum humidity on days 50-52 (after flowering). Minimum humidity (X7,X9) and lowest minimum humidity (X12, X14 and X15) in the second season, the combined data of the two seasons, and largest maximum humidity 
(X11and X13) and lowest minimum humidity (X14 and X15) in the first season and largest maximum humidity (X11) in the second season were positively (except of lowest minimum humidity on days 50-52 after flowering, X15) and highly correlated with flower and boll production.. Effect of maximum humidity varied markedly from the first season to the second one, where it was significantly correlated with the dependent variables in the first season, while the inverse pattern was true in the second season. This diverse effect may be due to the differences in the values of this factor in the two seasons; where it was on average $87 \%$ in the first season, and only $73 \%$ in the second season (Table 1). Also, was found that, when the average value of minimum humidity exceeded the half average value of maximum humidity, the minimum humidity can substitute the maximum humidity on affecting number of flowers or harvested bolls.

Table 2: Simple correlation coefficient (r) values between the independent variables, i.e. climatic factors and soil moisture status and the studied dependent variables, i.e. number of flowers and harvested bolls (number of retained bolls from the total number of daily tagged flowers in all selected plants at harvest) in the first season (I).

\begin{tabular}{|c|c|c|}
\hline \multirow{3}{*}{ Independent Variables (Irrigation and Climatic Factors) } & \multicolumn{2}{|c|}{ Dependent Variables (First Season) } \\
\hline & & \\
\hline & Flower & Boll \\
\hline (X1) Irrigation on day $1=1$. Otherwise, enter 0.0 & -0.1282 & -0.0925 \\
\hline $\begin{array}{l}\text { (X2) Irrigation on day } 0 \text { or }-1 \text { (the first and second day after the day of irrigation) }=1 \text {. Otherwise, } \\
\text { enter } 0.0\end{array}$ & -0.1644 & -0.1403 \\
\hline (X3) 1 is for the day prior to the day of irrigation. Otherwise, enter 0.0 & -0.0891 & -0.0897 \\
\hline $\begin{array}{l}\text { (X4) Number of days during days } 1 \text { (day of flowering) }-12 \text { (after flowering) that temperature } \\
\text { equaled or exceeded } 37.5^{\circ} \mathrm{C}\end{array}$ & 0.1258 & 0.1525 \\
\hline (X5) Range of temperature $\left[{ }^{\circ} \mathrm{C}\right]$ on day 1 (day of flowering) & -0.027 & -0.0205 \\
\hline (X6) Broadest range of temperature $\left[{ }^{\circ} \mathrm{C}\right]$ over days 1 (day of flowering)-12 (after flowering) & 0.055 & $0.1788^{+}$ \\
\hline (X7) Minimum humidity [\%] during day 1 (day of flowering) & 0.1492 & 0.1167 \\
\hline (X8) Maximum humidity [\%] during day 1 (day of flowering) & $0.2087^{++}$ & 0.1531 \\
\hline (X9) Minimum humidity [\%] during day 2 (after flowering) & 0.1079 & 0.1033 \\
\hline (X10) Maximum humidity [\%] during day 2 (after flowering) & 0.1127 & 0.0455 \\
\hline (X11) Largest maximum humidity [\%] on days 3-6 (after flowering) & $0.3905^{* *}$ & $0.2819 *$ \\
\hline (X12) Lowest minimum humidity [\%] on days 3-6 (after flowering) & 0.0646 & -0.0444 \\
\hline (X13) Largest maximum humidity [\%] on days 7-12 (after flowering) & $0.4499 * *$ & $0.3554^{*}$ \\
\hline (X14) Lowest minimum humidity [\%] on days 7-12 (after flowering) & $0.3522^{* *}$ & $0.1937^{+}$ \\
\hline (X15) Lowest minimum humidity [\%] on days 50-52 (after flowering) & $-0.3440^{* *}$ & $-0.4222^{* *}$ \\
\hline (X16) Daily light period(hour) & $-0.2430^{*}$ & -0.1426 \\
\hline
\end{tabular}

** Significant at $1 \%$ probability level, *Significant at $5 \%$ probability level. ++ Significant at $10 \%$ probability level, + Significant at $15 \%$ probability level. NS Means simple correlation coefficient is not significant at the $15 \%$ probability level Sawan [9].

Table 3: Simple correlation coefficient $(r)$ values between the independent variables, i.e. climatic factors and soil moisture status and the studied dependent variables, i.e. number of flowers and harvested bolls (number of retained bolls from the total number of daily tagged flowers in all selected plants at harvest) in the second season (II).

\begin{tabular}{|c|c|c|}
\hline \multirow{2}{*}{ Independent Variables (Irrigation and Climatic Factors) } & \multicolumn{2}{|c|}{ Dependent Variables (Second Season) } \\
\hline & Flower & Boll \\
\hline (X1) Irrigation on day $1=1$. Otherwise, enter 0.0 & -0.0536 & -0.0467 \\
\hline $\begin{array}{c}\text { (X2) Irrigation on day } 0 \text { or }-1 \text { (the first and second day after the day of irrigation) }=1 \text {. Otherwise, } \\
\text { enter } 0.0\end{array}$ & -0.1116 & -0.1208 \\
\hline (X3) 1 is for the day prior to the day of irrigation. Otherwise, enter 0.0 & -0.0929 & -0.0927 \\
\hline $\begin{array}{c}\text { (X4) Number of days during days } 1 \text { (day of flowering) }-12 \text { (after flowering) that temperature equaled } \\
\text { or exceeded } 37.5^{\circ} \mathrm{C}\end{array}$ & $-0.4192^{* *}$ & $-0.3981^{* *}$ \\
\hline (X5) Range of temperature $\left[{ }^{\circ} \mathrm{C}\right]$ on day 1 (day of flowering) & $-0.3779 * *$ & $-03858 * *$ \\
\hline (X6) Broadest range of temperature $\left[{ }^{\circ} \mathrm{C}\right]$ over days 1 (day of flowering)-12 (after flowering) & $-0.3849 * *$ & $-0.3841^{* *}$ \\
\hline (X7) Minimum humidity [\%] during day 1 (day of flowering) & $0.4522^{* *}$ & $0.4665^{* *}$ \\
\hline
\end{tabular}




\begin{tabular}{|c|c|c|}
\hline (X8) Maximum humidity [\%] during day 1 (day of flowering) & 0.0083 & 0.0054 \\
\hline (X9) Minimum humidity [\%] during day 2 (after flowering) & $0.4315^{* *}$ & $0.4374^{* *}$ \\
\hline (X10) Maximum humidity [\%] during day 2 (after flowering) & 0.0605 & 0.0532 \\
\hline (X11) Largest maximum humidity [\%] on days 3-6 (after flowering) & $0.2486^{++}$ & $0.2520^{*}$ \\
\hline (X12) Lowest minimum humidity [\%] on days 3-6 (after flowering) & $0.5783^{* *}$ & $0.5677^{* *}$ \\
\hline (X13) Largest maximum humidity [\%] on days 7-12 (after flowering) & 0.0617 & 0.0735 \\
\hline (X14) Lowest minimum humidity [\%] on days 7-12 (after flowering) & $0.4887^{* *}$ & $0.4691^{* *}$ \\
\hline (X15) Lowest minimum humidity [\%] on days 50-52 (after flowering) & $-0.6246^{* *}$ & $-0.6113^{* *}$ \\
\hline (X16) Daily light period (hour) & $-0.3677^{* *}$ & $-0.3609^{* *}$ \\
\hline
\end{tabular}

$* *$ Significant at $1 \%$ probability level, *Significant at $5 \%$ probability level. ++ Significant at $10 \%$ probability level, + Significant at $15 \%$ probability level. NS Means simple correlation coefficient is not significant at the $15 \%$ probability level Sawan [9].

Table 4: Simple correlation coefficient $(r)$ values between the independent variables, i.e. climatic factors and soil moisture status and the studied dependent variables, i.e. number of flowers and harvested bolls (number of retained bolls from the total number of daily tagged flowers in all selected plants at harvest) in the combined two seasons (I and II).

\begin{tabular}{|c|c|c|}
\hline \multirow{2}{*}{ Independent Variables (Irrigation and Climatic Factors) } & \multicolumn{2}{|c|}{ Dependent Variables (Combined Two Seasons) } \\
\hline & Flower & Boll \\
\hline (X1) Irrigation on day $1=1$. Otherwise, enter 0.0 & -0.0718 & -0.0483 \\
\hline $\begin{array}{l}\text { (X2) Irrigation on day } 0 \text { or }-1 \text { (the first and second day after the day of irrigation) }=1 \text {. Other- } \\
\text { wise, enter } 0.0\end{array}$ & -0.1214 & -0.1108 \\
\hline (X3) 1 is for the day prior to the day of irrigation. Otherwise, enter 0.0 & -0.0845 & -0.0769 \\
\hline $\begin{array}{l}\text { (X4) Number of days during days } 1 \text { (day of flowering) }-12 \text { (after flowering) that tempera- } \\
\text { ture equaled or exceeded } 37.5^{\circ} \mathrm{C}\end{array}$ & $-0.2234 *$ & $-0.1720^{++}$ \\
\hline (X5) Range of temperature $\left[{ }^{\circ} \mathrm{C}\right]$ on day 1 (day of flowering) & $-0.2551^{* *}$ & $-0.2479^{* *}$ \\
\hline (X6) Broadest range of temperature $\left[{ }^{\circ} \mathrm{C}\right]$ over days 1(day of flowering)-12 (after flowering) & $-0.2372^{* *}$ & $-0.1958^{*}$ \\
\hline (X7) Minimum humidity [\%] during day 1 (day of flowering) & $0.3369^{* *}$ & $0.3934^{* *}$ \\
\hline (X8) Maximum humidity [\%] during day 1 (day of flowering) & 0.0032 & -0.0911 \\
\hline (X9) Minimum humidity [\%] during day 2 (after flowering) & $0.3147^{* *}$ & $0.3815^{* *}$ \\
\hline (X10) Maximum humidity [\%] during day 2 (after flowering) & -0.0094 & -0.1113 \\
\hline (X11) Largest maximum humidity [\%] on days 3-6 (after flowering) & 0.0606 & -0.0663 \\
\hline (X12) Lowest minimum humidity [\%] on days 3-6 (after flowering) & $0.3849^{* *}$ & $0.4347^{* *}$ \\
\hline (X13) Largest maximum humidity [\%] on days 7-12 (after flowering) & -0.0169 & $-0.1442^{+}$ \\
\hline (X14) Lowest minimum humidity [\%] on days 7-12 (after flowering) & $0.3891^{* *}$ & $0.4219^{* *}$ \\
\hline (X15) Lowest minimum humidity [\%] on days 50-52 (after flowering) & $-0.3035^{* *}$ & $-0.2359^{* *}$ \\
\hline (X16) Daily light period (hour) & $-0.3039 * *$ & $-0.2535^{* *}$ \\
\hline
\end{tabular}

**Significant at $1 \%$ probability level, *Significant at 5\% probability level. ++Significant at 10\% probability level, +Significant at $15 \%$ probability level. NS Means simple correlation coefficient is not significant at the $15 \%$ probability level Sawan [9].

In the first season (Table 1) the average value of minimum humidity was less than half of the value of maximum humidity (30.2/85.6=0.35), while in the second season it was higher than half of maximum humidity $(39.1 / 72.9=0.54)$ (2016 a \& b).. Sunshine duration (X16) showed a significant negative relation with fruit production in the first and second season and the combined data of the two seasons except for boll production in the first season, which was not significant. Number of days during days 1 (day of flowering)-12 (after flowering) that temperature equalled or exceeded $37.5{ }^{\circ} \mathrm{C}$ (high temperature) (X4), range of temperature (temperature magnitude) on flowering day (X5) and broadest range of temperature over days 1 (day of flowering)-12 (after flowering) (X6), were also negatively correlated with flower and boll production in the second season and the combined data of the two seasons. The soil moisture status included, i.e., the day of irrigation, the first and second day after the day of irrigation, and the day prior to the day of irrigation, showed low and insignificant correlation to flower and boll production.

The positive relationship between humidity with flower and boll production means that low humidity rate reduces significantly cotton flower and boll production. This may be due to greater plant water deficits when humidity decreases. Also, the negative relation 
between each of maximum temperature (number of days during days 1 (day of flowering)-12 (after flowering) that temperature equalled or exceeded $37.5{ }^{\circ} \mathrm{C}(\mathrm{X} 4)$ ), range of temperature (temperature magnitude) on flowering day (X5), or sunshine duration (X16), with flower and boll production revealed that the increase in the values of these factors had a detrimental effect upon Egyptian cotton fruit production. Results obtained from the production stage of each season individually, and the combined data of the two seasons, indicated that relationships of some climatic variables with the dependent variables varied markedly from one season to another. This may be due to the differences between climatic factors in the two seasons as illustrated by the ranges and means shown in (Table 1). For example, maximum temperature (number of days during days 1 (day of flowering)-12 (after flowering) that temperature equalled or exceeded $37.5^{\circ} \mathrm{C}(\mathrm{X} 4)$, minimum humidity did not show significant relations in the first season, while that trend differed in the second season Sawan [9].

These results indicated that humidity was the most effective and consistent climatic factor affecting boll production. As the sign of the relationship was positive, this means that the sensible decrease in humidity would cause a significant reduction in boll number. Thus, applying specific treatments such as an additional irrigation, and use of plant growth regulators, which would decrease the deleterious effect of evaporation after boll formation and hence contribute to an increase in cotton bowl production and retention, and the consequence is an increase in cotton yield. In this connection, Moseley [13] stated that methanol has been reported to increase water use efficiency, growth and development of C3 plants in arid conditions, under intense sunlight. In field trials cotton cv. DPL-50 (Gossypium hirsutum), was sprayed with a nutrient solution $\left(1.33 \mathrm{lbN}+0.27 \mathrm{lb} \mathrm{Fe}+0.27 \mathrm{lbZn}\right.$ acre $\left.^{-1}\right)$ or $30 \%$ methanol solution at a rate of 20 gallons acre ${ }^{-1}$, or sprayed with both the nutrient solution and methanol under two soil moisture regimes (irrigated and dry land). The foliar spray treatments were applied 6 times during the

\section{Multiple linear regression models, beside contribution of climatic factors and soil moisture status to variations in the dependent variables}

Table 5: Model obtained for cotton production variables, i.e. the number of flowers $\left(Y_{1}\right)$ and bolls $\left(Y_{2}\right)$ per cotton plant as functions of climatic data and soil moisture status in each of an overall the two seasons.

\begin{tabular}{|c|c|c|}
\hline Season & Model & $\mathbf{R}^{2}$ \\
\hline \multirow{2}{*}{ Season I $(n=68)$} & $Y_{1}=-557.54+6.35 \times 6+0.65 \times 7+1.92 \times 11+4.17 X 13+2.88 \times 14-1.90 \times 15-5.63 X 16$ & 0.63 \\
\hline & $Y_{2}=-453.93+6.53 X 6+0.61 X 7+1.80 X 11+2.47 X 13+1.87 X 14-1.85 X 15$ & 0.53 \\
\hline \multirow{2}{*}{ Season $\operatorname{II}(n=62)$} & $Y_{1}=-129.45+25.36 \times 1+37.02 X 4+1.48 X 7+1.69 X 9+4.46 \times 12+2.55 \times 14-4.73 X 15$ & 0.72 \\
\hline & $Y_{2}=-130.23+24.27 X 1+35.66 \times 4+1.42 X 7+1.61 X 9+4.00 \times 12+2.18 \times 14-4.09 X 15$ & 0.71 \\
\hline \multirow{2}{*}{ Combined data: I \& II (n=130) } & $Y_{1}=-557.36+6.82 X 6+1.44 X 7+0.75 X 9+2.04 X 11+2.55 X 12+2.01 X 13+3.27 X 14-2.15 X 15$ & 0.57 \\
\hline & $Y_{2}=-322.17+6.41 X 6+1.20 \times 7+0.69 \times 9+1.81 X 11+2.12 \times 12+2.35 \times 14-2.16 \times 15$ & 0.53 \\
\hline
\end{tabular}

(X1) Irrigation on day 1=1. Otherwise, enter 0.0. (X4) Number of days during days 1 (day of flowering)-12 (after flowering) that temperature equalled or exceeded $37.5{ }^{\circ} \mathrm{C}$. (X6) Broadest range of temperature [ ${ }^{\circ} \mathrm{C}$ ] over days 1 (day of flowering)-12 (after flowering). (X7) Minimum humidity [\%] during day 1 (day of flowering). (X9) Minimum humidity [\%] during day 2 (after flowering). (X11) Largest maximum humidity [\%] on days 3-6 (after flowering). (X12) Lowest minimum humidity [\%] on days 3-6 (after flowering). (X13) Largest maximum humidity [\%] on days 7-12 (after flowering). (X14) Lowest minimum humidity [\%] on days 7-12 (after flowering). (X15) Lowest

minimum humidity [\%] on days 50-52 (after flowering). (X16) Daily light period (hour). All entries significant at 1\% level Sawan [9]. 
An attempt was carried out to investigate the effect of climatic factors and soil moisture status on cotton production via prediction models responsible for the majority of total variability in cotton flower and boll production. Hence, regression models were established using the stepwise multiple regression technique to express the relationship between each of the number of flowers and bolls plant ${ }^{-1}(\mathrm{Y})$, with the climatic factors beside soil moisture status (Table 5); Sawan [9]. The models obtained for each of the two dependent variables, i.e. number of flowers $\left(\mathrm{Y}_{1}\right)$ and bolls plant ${ }^{-1}$ $\left(\mathrm{Y}_{2}\right)$ in each season and for combined data from the two seasons clarified the following:

Humidity [\%] was the most important climatic factor affecting flower and boll production in Egyptian cotton [Minimum humidity during day 1 (day of flowering) (X7), minimum humidity during day 2 (after flowering) (X9), largest maximum humidity on days 3-6 (after flowering) (X11), lowest minimum humidity on days 3-6 (after flowering) (X12), largest maximum humidity on days 7-12 (after flowering) (X13), lowest minimum humidity on days 7-12 (after flowering) (X14) and lowest minimum humidity on days 5052 (after flowering) (X15).Sunshine duration (Daily light period (hour) (X16)) is the second climatic factor of importance affecting production of flowers and bolls.

Maximum (high) temperature (Number of days during days 1 (day of flowering)-12 (after flowering) that temperature equalled or exceeded $37.5^{\circ} \mathrm{C}$ (high temperature) (X4).), broadest range of temperature $\left[{ }^{\circ} \mathrm{C}\right]$ over days 1 (day of flowering)-12 (after flowering) (X6) and soil moisture status on the day of irrigation (X1) made a contribution affecting on flower and boll production but less than humidity and sunshine duration/day. The soil moisture status included, i.e., the first and second day after the day of irrigation (X2) and the day prior to the day of irrigation (X3), and the climatic factors, i.e. range of temperature on day 1 (day of flowering) (X5), maximum humidity during day 1 (day of flowering) (X8) and maximum humidity during day 2 (after flowering) (X10) were not included in the equations since they had very little effect on production of cotton flowers and bolls Sawan [9] The sign of the partial regression coefficient for an independent variable (climatic factors or soil moisture status) indicates its effect on the production value of the dependent variable (flowers or bolls). The positive value of the partial regression coefficient is interpreted as meaning that the higher the rate of the variable, the higher is the expected value of the production variable, and the inverse is true Sawan [9].

Humidity showed the highest contribution to the variation in both flower and boll production. This finding can, however, be explained in the light of results found by Ward \& Bunce [17] in sunflower (Helianthus annuus). They stated that decreases of humidity at both leaf surfaces reduced photosynthetic rate of the whole leaf for plants grown under a moderate temperature and medium light level. Kaur \& Singh [18] found in cotton that flower number was decreased by water stress, particularly when applied at flowering. Seed cotton yield was about halved by water stress applied at flowering, slightly decreased by stress at boll formation, and not significantly affected by stress in the vegetative state (6-7 weeks after sowing).
Reddy KR [19] found that the number of fruiting sites per plant increased linearly as temperature increased to $30 / 22{ }^{\circ} \mathrm{C}$ (day/ night temperature regimes) but declined by over $50 \%$ at $35 / 27{ }^{\circ} \mathrm{C}$. Plants grown at $40 / 32{ }^{\circ} \mathrm{C}$ did not produce reproductive structures during the entire $64 \mathrm{DAE}$ (days after emergence) period. Optimum temperature for reproductive growth in Pima cotton in terms of number of fruiting branches, length and nodes per branch was $30 / 22{ }^{\circ} \mathrm{C}$, and this was also the optimum temperature for flower bud and boll production and retention. Vegetative growth increases at temperatures above $30 / 22{ }^{\circ} \mathrm{C}$, these increasing main stem height and leaf area at nodes initiated higher on the main stem. More flower buds and bolls were aborted at $35 / 27^{\circ} \mathrm{C}$ than at the optimum, or lower temperature. Plants grown at $40 / 32{ }^{\circ} \mathrm{C}$ remained vegetative during the $64 \mathrm{DAE}$ periods. These results emphasize the need for heat-tolerant cultivars in today's cotton production environments. Heat-tolerant cultivars will be even more essential in the future, as global warming increases Sawan [9].

Hodges [20] found that cotton (Gossypium hirsutum) fruit retention decreased rapidly as the time of exposure to $40{ }^{\circ} \mathrm{C}$ increased. Warner \& Burke [21] indicated that the cool-night inhibition of cotton (Gossypium hirsutum) growth is correlated with biochemical limitation on starch mobilization in source leaves, which result in a secondary inhibition of photosynthesis, even under optimal temperature during the day. Reddy [22] observed that when cotton cv DPL-50 plants grown in growth chambers were exposed for $70 \mathrm{~d}$ to natural light levels with average temperature of $17.8,18.7,22.7,26.6$ or $30.6{ }^{\circ} \mathrm{C}$, number of squares and bolls produced were increased with increased temperature up to $30.6^{\circ} \mathrm{C}$.

Reddy KR [23] observed that when cotton cv DPL-51 (Upland cotton) was grown in controlled environments with natural solar radiation, flower and fruit retention was very low at an ambient temperature from 31.3 to $33^{\circ} \mathrm{C}$ plus 5 or $7{ }^{\circ} \mathrm{C}$. It was concluded that cotton would be severely damaged by temperatures above those presently observed during midsummer in the cotton belt in USA. Also, they concluded that the grower could minimize boll abscission where high temperature and low humidity occur by growing heat-tolerant cultivars, proper management of planting date, adequate fertilization, optimum plant density, and applying suitable irrigation regime which would avoid drought stress. Wise [24] indicated that restrictions to photosynthesis could limit plant growth at high temperature in a variety of ways. In addition to increasing photorespiration, modernity high temperatures (35-42 ${ }^{\circ} \mathrm{C}$ ) can cause direct injury to the photosynthetic apparatus. Both carbon metabolism and thylakoid reactions have been suggested as the primary site of injury at these temperatures.

Regression models obtained demonstrate of each independent variable under study as an efficient and important factor. Meanwhile, they explained a sensible proportion of the variation in flower and boll production, as indicated by their $\mathrm{R}^{2}$, which ranged between 0.53-0.72. These results agree with Miller [25] in their regression study of the relation of yield with rainfall and temperature. They suggested that the other 0.50 of variation related to management practices, which can be the same in this study. Thus, an accurate climatic forecast for the effect of the 5-7-day period provide an 
opportunity to avoid any possible adverse effects of unusual climatic conditions before flowering or after boll formation by utilizing additional treatments and/or adopting proper precautions to avoid flower and boll reduction Sawan [12], Sawan [26]; Sawan [27].

The main climatic factors from this study affecting the number of flowers and bolls, and by implication yield, are, minimum humidity (water stress) and sunshine duration and, with being by far the most important factor. Various activities have been suggested to partially overcome water stress Sawan [9]. Zhao \& Oosterhuis [28] found that under water stress, in a growth chamber, cotton plants treated with the plant growth regulator PGR-IV developed higher dry weight of roots and floral buds than the untreated waterstressed plants. Under mild water stress, Meek [29] found that the application of three or six kg glycin betaine (PGR) ha ${ }^{-1}$ increased yields.

Temperature conditions during the reproduction growth stage of cotton in Egypt do not appear to limit growth even though they are above the optimum for cotton growth Sawan [9]. This is contradictory to the finding of Holaday [30]. A possible reason for that contradiction is that the effects of soil moisture status and humidity were not taken into consideration in the research studies conducted by other researchers in other countries. The matter of fact is that temperature and evaporation are closely related to each other to such an extent that the higher evaporation rate could possible mask the effect of temperature. Sunshine duration and minimum humidity appeared to have secondary effects, yet they are in fact important players Sawan [9]. The importance of sunshine duration has been alluded to by Moseley [13]; Oosterhuis [28] Also, Mergeai \& Demol [31] found that cotton yield was assisted by intermediate relative humidity.

Other workers, studying the effect of weather factors on cotton boll production and retention and, in turn, yield, found different relationships. They found that temperature was often the major factor affecting cotton growth. In this respect, Holaday [30] in growth chamber experiments with cotton cv. Coker 312 showed that cool nighttimes $\left(15\right.$ or $19^{\circ} \mathrm{C}$ ) reduced photosynthetic efficiency compared with warm nighttimes $\left(28^{\circ} \mathrm{C}\right)$. This is ascribed to reducing stomata conductance, resulting in lower sucrose levels during the day and reduced ability to export sucrose from the leaf, to storage places. Oosterhuis [32] reported that the reason for low and variable cotton yields in Arkansas is the unusually high insect pressures and the development of the boll load during an exceptionally hot, dry August. Solutions to these problems were suggested such as selection of tolerant cultivars, effective and timely insect and weed control, adequate irrigation regime, use of proper crop monitoring techniques and application of plant growth regulators. Reddy KR [33] found that when Upland cotton (G. hirsutum) cv. DPL-51 was grown in naturally lit plant growth chambers at $30 / 22{ }^{\circ} \mathrm{C}$ day/ night temperatures from sowing until floral bud production, and at $20 / 12,25 / 17,30 / 22,35 / 27$ and $40 / 32{ }^{\circ} \mathrm{C}$ for $42 \mathrm{~d}$ after floral bud production, fruit retention was severely curtailed at the two higher temperatures compared with $30 / 22{ }^{\circ} \mathrm{C}$. Species/cultivars that retain fruits at high temperatures would be more productive both in the present-day cotton production environments and even more so in a future warmer world Sawan [26]; Sawan [27].

Miller [25] reported that regression analysis of the relationship of yield with rainfall and temperature (data gathered during the period 1968-1992) indicated that in most cases about $50 \%$ of the yield variation for dry land cotton could be explained by a combination of weather factors. The other $50 \%$ of yield variation was ascribed to management of cultural practices. Thus, an accurate climatic forecast for the effect of the 5-7-day period during flowering may provide an opportunity to avoid possible adverse effects of unusual climatic conditions before flowering or after boll formation by utilizing additional treatments and/or adopting proper precautions to avoid flower and boll reduction Sawan [34]; Sawan [1].

\section{Conclusion}

From the results obtained in the present study, it could be generally concluded that minimum humidity and sunshine duration, were the most significant climatic factors affecting cotton flower and boll production and retention in Egyptian cotton beside soil moisture status. The positive correlation between minimum humidity value along with the negative correlation between each of high air temperature and sunshine duration with flower and boll formation, indicate that high value of minimum humidity, short period of sunshine duration and low value of temperature would enhance flower and boll formation. Temperature appeared to be less important in the reproduction growth stage of cotton in Egypt than minimum humidity (water stress) and sunshine duration. These findings concur with those of other researchers except for the importance of temperature. A possible reason for that contradiction is that the effects of evaporation rate and humidity were not taken into consideration in the research studies conducted by other researchers in other countries. The matter of fact is that temperature and evaporation are closely related to each other to such an extent that the higher evaporation rate could possible mask the effect of temperature. Water stress is in fact the main player and other authors have suggested means for overcoming its adverse effect, which could be utilized as for the Egyptian cotton. It must be kept in mind that although the reliable prediction of the effects of the aforementioned climatic factors could lead to higher yields of cotton, yet only $50 \%$ of the variation in yield could be statistically explained by these factors and hence consideration at the same time should be given to the management practices presently being in use.

The least important independent variable was soil moisture status. In conclusion, the early prediction of possible adverse effects of climatic factors could pave the way for adopting adequate precautions regarding the effect of certain climatic factors on production of Egyptian cotton Sawan [9]. This would be useful to minimize the deleterious effects of these factors, through the application of adequate management practices, i.e. adequate irrigation regime Orgas [35] and Ooterhuis [36], as well as utilization of specific plant growth regulators Moseley [12], Zhao \& Oosterhuis [36]; Meek [29]. Which would limit and control 
the negative effects of some climatic factors, and this will lead to an improvement in cotton yield production in Egypt $[36,37]$ Nevertheless, it could be stated that during the production stage, an accurate weather forecast for the next 5-7 days would provide an opportunity to avoid any adverse effects of climatic factors on cotton production $[38,39]$. It would be useful to minimize the deleterious effects of those factors through utilizing proper cultural practices which would limit and control their negative effects [4042], and this will lead to an improvement in cotton yield [43-48]. Methods of early detection of stress in cotton in order to (may) allow timely management inputs were investigated Sawan [27].

\section{References}

1. Sawan ZM (2015) Statistical methods to evaluate the relationship between climatic factors during the development periods of flowering and boll formation and cotton production. International Journal of Environmental Science \& Natural Resources 1(1): 1-8.

2. Guinn G (1982) Causes of square and boll shedding in cotton. USDA Tech Bull 1672. United States Department of Agriculture, Washington, USA, pp. 1-24.

3. Xiao JF, Liu ZG, Yu XG, Zhang JY, Duan AW (2000) Effects of different water application on lint yield and fiber quality of cotton under drip irrigation. Acta Gossypii Sinica 12(4): 194-197.

4. Barbour MM, Farquhar GD (2000) Relative humidity and ABA induced variation in carbon and oxygen isotope ratios of cotton leaves. Plant, Cell \& Environ 23(5): 473-485.

5. Burke JJ, Mahan JR, Hatfield JL (1987) Crop specific thermal kinetic windows in relation to wheat and cotton biomass production. Agron 80(4): 553-556.

6. Schrader SM, Wise RR, Wacholtz WF, Ort DR, Sharkey TD (2004) Thylakoid membrane responses to moderately high leaf temperature in pima cotton. Plant Cell Environ 27(6): 725-735.

7. Sawan ZM (2014a) Climatic factors: evaporation, sunshine, relative humidity, soil and air temperature and cotton production. Annual Research \& Review in Biology 4(18): 2835-2855.

8. Zhou ZG, Meng YL, Shi P, Shen YQ, Jia ZK (2000) Study of the relationship between boll weight in wheat-cotton double cropping and meteorological factors at boll forming stage. Acta Gossypii Sinica 12(3): 122-126.

9. Sawan ZM, Hanna LI, McCuistions WL, Foote RJ (2010) Egyptian cotton (Gossypium barbadense) flower and boll production as affected by climatic factors and soil moisture status. Theoretical and Applied Climatology 99(1-2): 217-227.

10. Cady FB, Allen DM (1972) Combining experiments to predict future yield data. Agron J 64: 211-214.

11. (1985) SAS Users guide: statistics. ( $5^{\text {th }}$ edn), SAS Institute SAS, Cary, North Carolina, USA.

12. Sawan ZM (2014b) Nature relation between climatic variables and cotton production. Journal of Stress Physiology \& Biochemistry 9: 251278.

13. Moseley D, Landivar JA, Locke D (1994) Evaluation of the effect of methanol on cotton growth and yield under dry-land and irrigated conditions. In: Diego S (Ed.), Proceedings of the Belt wide Cotton Conferences, National Cotton Council, Memphis, USA, pp. 1293-1294.

14. Bhatt JG (1977) Growth and flowering of cotton (GossypiumhirsutumL.) as affected by day length and temperature. J Agric Sci 89: 583-588.

15. Boyer JS, Johnson RR, Saupe SG (1979) After noon water deficits and grain yields in old and new soybean cultivars. Agron J 729(6): 981-986.
16. Human JJ, Du Toit D, Bezuidenhout HD, De Bruyn LP (1990) The influence of plant water stress on net photosynthesis and yield of sunflower (Helianthus annuus L.). J Agron Crop Sci 164(4): 231-241.

17. Ward DA, Bunce JA (1986) Responses of net photosynthesis and conductance to independent changes in the humidity environments of the upper and lower surfaces of leaves of sunflower and soybean. J Exp Bot 37(12): 1842-1853.

18. Kaur, Singh OS (1992) Response of growth stages of cotton varieties to moisture stress. Indian J Plant Physiol 35: 182-185.

19. Reddy KR, Mc Kinion JM, Wall GW, Bhattacharya NC, Hodges HF, Bhattacharya S (1991) Effect of temperature on Pima growth and development. In: Antonio S (Ed.), Proceeding of the Belt wide Cotton Conferences. National Cotton Council, Memphis, TN, USA, p. 841.

20. Hodges HF, Reddy KR, Mc Kinion JM, Reddy VR (1993) Temperature effects on cotton. Miss Agric For Exp Stn Tech Bull Vol. 990.

21. Warner DA, Burke JJ (1993) Cool night temperature alter leaf starch and photosystem II Chlorophyll fluorescence in cotton. Agron J 85(4): 836840.

22. Reddy VR, Reddy KR, Acock B (1995b) Carbon dioxide and temperature interactions on stem extension, node initiation, and fruiting in cotton. Agric Ecosyst Environ 55(1): 17-28.

23. Reddy KR, Hodges HF, McKinion JM (1996) Can cotton crops be sustained in future climates? In: Proceedings of the Belt wide Cotton Conferences, Nashville. National Cotton Council, Memphis, TN, USA, pp. 1189-1196.

24. Wise RR, Olson AJ, Schrader SM, Sharkey TD (2004) Electron transport is the functional limitation of photosynthesis in field grown pima cotton plants at high temperature. Plant Cell Environ 27(6): 717-724.

25. Miller JK, Krieg DR, Paterson RE (1996) Relationship between dry land cotton yields and weather parameters on the Southern Hig Plains. Proceedings of the Belt wide Cotton Conferences, January 9-12, Nashville. National Cotton Council, Memphis, USA, pp. 1165-1166.

26. Sawan ZM (2016a) Climatic factors, cotton production: studying its relationships by different applied statistical methods. Journal of Statistics and Mathematical 2: 109-120.

27. Sawan ZM (2016b) Different applied mathematics and statistics methods to evaluate the response of cotton production to climatic variables. Elixir International Journal, Elixir Statistics 92: 39348-39364.

28. Zhao Du Li, Oosterhuis D (1997) Physiological response of growth chamber-grown cotton plants to the plant growth regulator PGR-IV under water-deficit stress. Environ Exp Bot 38(1): 7-14.

29. Meek CR, Oosterhuis DM, Steger AT (1999) Drought tolerance and foliar sprays of glycine betaine. In: Proceedings of the Beltwide Cotton Conferences, Orlando. National Cotton Council, Memphis, USA, pp. 559561.

30. Holaday AS, Haigler CH, Srinivas NG, Martin LK, Taylor JG (1997) Alterations of leaf photosynthesis and fiber cellulose synthesis by cool night temperatures. In Proceedings Belt wide Cotton Conferences, New Orleans. National Cotton Council, Memphis, USA, pp. 1435-1436.

31. Mergeai G, Demol J (1991) Contribution to the study of the effect of various meteorological factors on production and quality of cotton (Gossypium hirsutum L.) fibers. Bull Res Agron Gembloux 26: 113-124.

32. Oosterhuis DM (1997) Effect of temperature extremes on cotton yields in Arkansas. In: Proceedings of the Cotton Research Meeting, held at Monticello, Arkansas, USA, Oosterhuis DM, Stewart, JM (Eds.), Special Report Agricultural Experiment Station, Division of Agriculture, University of Arkansas 183: 94-98.

33. Reddy KR, Robana RR, Hodges HF, Liu XJ, Mckinion JM (1998) Interactions of $\mathrm{CO}_{2}$ enrichment and temperature on cotton growth and leaf characteristics. Environ Exp Bot 39(2): 117-129. 
34. Sawan ZM (2013) Studying the relationship between climatic factors and cotton production by different applied methods. Journal of Stress Physiology \& Biochemistry 9(4): 251-278.

35. Orgaz F, Mateos L, Fereres E (1992) Season length and cultivar determine the optimum evapotranspiration deficit in cotton. Agron J 84(4): 700706.

36. Oosterhuis DM (1999) Yield response to environmental extremes in cotton. In: Proceedings of the Cotton Research Meeting. Fayetteville, USA; Arkansas Agricultural Experiment Station, University of Arkansas. Special Report - Arkansas Agricultural Experiment Station 193: 30-38.

37. Draper NR, Smith H (1966) Applied regression analysis. John Wiley \&Sons, NewYork, USA.

38. Gutiérrez MasJC, LópezM (2003) Heat, limitation of yields of cotton in Andalucia. Agricultura, Revista Agropecuaria72: 690-692.

39. Hearn AB, Constable, GA (1984) Cotton. In: Goldsworth PR, Fisher NM (Eds.), The physiology of tropical food crops, John Wiley \& Sons, New York, USA, pp. 495-527.

40. Luz MJ da S e, Bezerra JRC, Barreto AN (1998) Effect of water stress at different growth stages of cotton cv. BR 1 in Condada, Paraiba, on its phenology and water use efficiency. Revista de Oleaginosas e Fibrosas 2(3): 209-214.

41. Reddy KR, Davidonis GH, Johnson AS, Vinyard BT (1999) Temperature regime and carbon dioxide enrichment alter cotton boll development and fiber properties. Agron J 91(5): 851-858.
42. Reddy KR, Doma PR, Mearns LO, Boone MYL, Hodges HF, et al. (2002) Simulating the impact of climate change on cotton production in the mississippi delta. Climate Res 22: 271-281.

43. Reddy KR, Hodges HF, Mc Kinion JM (1993) Temperature effects on Pima cotton leaf growth. Agron J 85(3): 681-686.

44. Reddy KR, Hodges HF, Mc Kinion JM (1995a) Carbon dioxide and temperature effects on Pima cotton growth. Agric Ecosyst Environ 54(12): 17-29.

45. Reddy KR, Hodges HF, Reddy VR (1992) Temperature effects on cotton fruit retention. Agron J 84(1): 26-30.

46. Reddy VR, Reddy KR, Hodges HF, Baker DN (1990) The effect of temperature on growth, development and photosynthesis of cotton during the fruiting period. Monograph-British Society for Plant Growth Regulation 20: 97-110.

47. Wang X, Whisler FD (1994) Analyses of the effects of weather factors on predicted cotton growth and yield. Bull Mississippi Agric For Exp Stn 1014: 51 .

48. Yuan J, Shi Y, Pan ZX, Liu XL, Li CQ (2002) Effect of meteorological conditions on cotton yield in arid farmland. China Cotton 29: 10-11.
Creative Commons Attribution 4.0

International License

For possible submissions Click Here

\section{Submit Article}

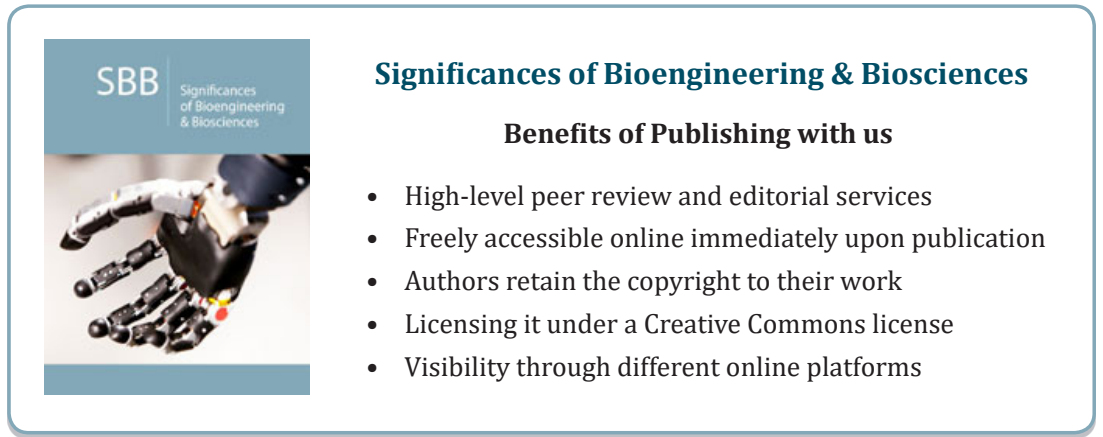

